\title{
Incidence and sources of native and prosthetic joint infection: a community based prospective survey
}

Carola J E Kaandorp, Huibert J Dinant, Mart A F J van de Laar, Hein J Bernelot Moens, A Pieter A Prins, Ben A C Dijkmans

\begin{abstract}
Objectives-To determine the incidence and sources of bacterial arthritis in the Amsterdam health district and the maximum percentage of cases that theoretically would be preventable.

Methods-Patients with bacterial arthritis diagnosed between 1 October 1990 and 1 October 1993 were prospectively reported to the study centre by all 12 hospitals serving the district. Data were gathered on previous health status, source of infection, and microorganisms involved.

Results-188 episodes of bacterial arthritis were found in 186 patients. Most of the 38 children were previously healthy. Fifty per cent of the adults were 65 years or older. Of the adults $84 \%$ had an underlying disease, in $59 \%$ a joint disorder. Joint surgery constituted the largest part of direct infections (33\%) and skin defects were the most important source of haematogenous infections (67\%). Infection of joints containing prosthetic or osteosynthetic material by a known haematogenous source occurred 15 times $(8 \%)$. Staphylococcus aureus was the causative organism in $44 \%$ of all positive cultures.

Conclusion-The incidence of bacterial arthritis was 5.7 per 100000 inhabitants per year. Preventive measures directed to patients with prosthetic joints or osteosynthetic material, and a known haematogenous source would have prevented at most $8 \%$ of all cases.
\end{abstract}

(Ann Rheum Dis 1997;56:470-475)

The mortality of bacterial arthritis ranges from 10 to $25 \% .^{1-4}$ Permanent loss of joint function occurs in 25 to $50 \%$ of all surviving patients. ${ }^{1-4}$ These percentages are higher for patients with underlying joint disorders, partly because early diagnosis of bacterial arthritis is often difficult. ${ }^{3-5}$ For the general population the incidence of bacterial arthritis has been estimated to be two cases per 100000 inhabitants per year. ${ }^{67}$ Estimates of the incidence of bacterial arthritis in patients with rheumatoid arthritis range between 28 and 38 per 100000 inhabitants per year, ${ }^{7-9}$ and in patients with joint prostheses between 40 and 68 per 100000 inhabitants per year. ${ }^{1011}$ The increased risk and generally poorer outcomes among patients with underlying joint disorders suggest a need for preventive measures.
Bacterial arthritis is usually haematogenous. ${ }^{5}$ Haematogenous infections can, theoretically, be prevented by giving antibiotics before or during bacteraemia. Guidelines analogous to those for the prophylaxis of endocarditis have been proposed for the treatment of patients with joint prostheses. ${ }^{12-15}$ In general, these are that antibiotics should be given before surgery or other interventions with risk of bacteraemia and as early as possible in the event of infections. Physicians and dentists called upon to put such measures into practice have objected that there is too little evidence to justify such a regimen. ${ }^{16}{ }^{17}$ Preventive measures may be indicated only in cases of increased risk. ${ }^{18}$

In 1990 we started a large scale study on risk factors, ${ }^{19}$ on outcome, ${ }^{4}$ and on incidence and sources of bacterial arthritis, to gather evidence for national guidelines for prophylaxis of bacterial arthritis. This report describes all cases of bacterial arthritis detected during three years in the Amsterdam health district. It extends on previous reports describing the 37 cases with pre-existent joint diseases attending a rheumatic disease clinic from the study on risk factors, and the 154 patients (seen before April 1993), in whom the outcome was assessed in a follow up study. Here, we report the incidence of bacterial arthritis and details regarding route of infection, joints, microorganisms, and sources to get an impression to what extent prevention had been possible.

\section{Methods}

This study was carried out in the Amsterdam health district, the Netherlands, which has 1.1 million inhabitants. ${ }^{20}$

Cases in which the diagnosis of bacterial arthritis or prosthetic joint infection was made between 1 October 1990 and 1 October 1993 were included. Criteria for the diagnosis were derived from those of Newman: positive culture or direct identification of microorganisms in synovial fluid or tissue, or macroscopic pus produced by arthrocentesis or a clinical presentation of synovitis with rapidly progressive joint destruction on radiographs, or a strong clinical suspicion without alternative explanation. ${ }^{21}$

The detection of cases occurred by several routes. The orthopaedic surgeons, internists, rheumatologists, and paediatricians of the district's 12 general hospitals were informed before the start of the study and agreed to report all cases of joint infection. The seven 
bacteriological laboratories in the district reported all positive results of cultures of synovial fluid or tissue. In addition, the diagnosis registries in the district reported all patients with a diagnosis of joint infection. After obtaining oral informed consent from all patients the medical records were consulted. One investigator (CJEK) recorded the patient's age and current status of health, any underlying joint disorder, the joints involved, whether there were prosthetic joints or joints containing osteosynthesis material, the source of infection, the causative organism, and the basis upon which the diagnosis had been made. Patients with concomitant chronic diseases likely to impair host defences such as cancer, acquired immunodeficiency syndrome (AIDS), diabetes mellitus, chronic obstructive lung disease, renal insufficiency, and patients using immunosuppressive or illicit intravenous drugs, were labelled as immunocompromised patients.

Two different pathogenetic routes of infection were recognised: direct and haematogenous. Bacterial arthritis was considered as direct in origin in case of suspicious clinical course (wound drainage, incomplete pain relief, persistent increase in sedimentation rate, early radiographic signs of loosening, without another identified source, for example, cutaneous infection, urinary tract infection $)^{22}$ after an invasive joint procedure, or penetrating trauma, or local spread in the course of osteomyelitis, cellulitis, abscesses, tenosynovitis or septic bursitis. Otherwise it was considered to be haematogenous. An extra-articular infection or intervention was considered to be the source of infection if it had occurred less than three months before the onset of bacterial arthritis and the species isolated from the infected joint was compatible with the hypothetical source. Although with corticosteroids injected joints are temporarily more susceptible to haematogenous infection, ${ }^{23}$ we classified infections secondary to intra-articular injections as direct.

We considered cultures that grew Staphylococcus epidermidis or Propionibacterium acnes to be positive only if a Gram stain showed large numbers of leucocytes and bacteria or if a second culture produced the same result. We recorded an episode of bacterial arthritis in a previously affected patient as a new case if the preceding episode had been adequately treated and the patient had remained free of symptoms for an intervening period of at least three months. Cases of infectious spondylodiscitis were not included in this study.

\section{Results}

INCIDENCE

One hundred eighty eight cases of bacterial arthritis were registered during the three year course of the survey. This yields an incidence of 5.7 per 100000 inhabitants per year $(95 \%$ confidence intervals: $4.9,6.5)$. The cases were distributed over 186 patients, 97 men (52\%) and 89 women $(48 \%)$. There were two peaks in the age specific incidence: children below the age of 5 made up $6 \%$ of the study population, ${ }^{20}$ but accounted for $14 \%$ of the registered cases; adults above the age of 64 made up $13 \%$ of the study population, but accounted for $39 \%$ of the registered cases.

\section{CLINICAL PROFILES}

In 157 cases bacterial arthritis was diagnosed on the basis of positive cultures or direct identification of microorganisms in joint fluid or synovial tissue, in 19 cases on the presence of pus in the affected joint, and in eight cases on the rapidly progressive joint destruction on radiographs. Three children and one adult were diagnosed as having bacterial arthritis on the basis of the typical clinical picture together with positive cultures of blood and material from the assumed source of infection.

Table 1 gives the clinical characteristics of the patients. Of the 38 children 31 had been previously healthy, while seven had a concomitant disease-in two cases disorders of neutrophil function.

Of the 150 adults 23 had no underlying disorders. Thirty seven adult patients were subject to disorders that directly or indirectly compromised their host defences. These were: use of intravenous drugs in 14 patients (six of them infected with the human immunodeficiency virus (HIV)), diabetes mellitus in 11 patients, renal insufficiency in four (two of them requiring regular dialysis), haematological malignancy in three, AIDS in two, and chronic osteomyelitis in two. In one each: polymyalgia rheumatica treated with prednisone, chronic obstructive pulmonary disease intermittently treated with prednisone, leprosy, and misuse of alcohol.

Eighty nine patients ( $47 \%$ of all cases) had underlying joint disorders. These were rheumatoid arthritis and osteoarthritis each in 32 patients. Other joint diseases, which occurred in one patient each, were juvenile chronic arthritis, psoriatic arthritis, and ankylosing spondylitis. One patient had a history of tuberculous coxitis. In the remaining 21 patients joints had been damaged or had been replaced in the past because of traumatic damage. The immune system of 25 of these 89 patients was compromised as a result of medication (18 patients), diabetes mellitus (6 patients), and breast cancer (4 patients).

\section{JOINTS INVOLVED}

In total, 214 infected joints were registered (table 2); knees (48\%) and hips (21\%) were most commonly affected. Among children ankles were involved in $21 \%$, knees in $32 \%$, and hips in $34 \%$. Among adults all except one of the 22 infected hips contained a prosthesis or osteosynthesis material. Among the adult patients in whom only native joints were involved were three patients with prostheses in un-involved joints. Of the 214 infected joints $58(27 \%)$ contained prosthetic or osteosynthetic material; 25 were haematogenously infected and 33 by a 'direct' cause such as joint surgery.

There were 18 patients with polyarticular bacterial arthritis, among them two children. One of them had been healthy before infection, 
Table 1 Cases of bacterial arthritis or infected joint prosthesis according to clinical category and infection route

\begin{tabular}{|c|c|c|c|c|c|}
\hline Patient category & $\begin{array}{l}\text { Total } \\
(n=188)\end{array}$ & $\begin{array}{l}\text { Haematogenous } \\
\text { infection of } \\
\text { native joints } \\
(n=101)\end{array}$ & $\begin{array}{l}\text { Haematogenous } \\
\text { infection of joints with } \\
\text { prosthetic or } \\
\text { osteosynthetic material } \\
(n=25)\end{array}$ & $\begin{array}{l}\text { Direct } \\
\text { infection of } \\
\text { native joints } \\
(n=29)\end{array}$ & $\begin{array}{l}\text { Direct infection of } \\
\text { joints with } \\
\text { prosthetic or } \\
\text { osteosynthetic } \\
\text { material }(n=33)\end{array}$ \\
\hline Children & 38 & 36 & - & 2 & - \\
\hline Previously healthy & 31 & 29 & & 2 & \\
\hline Concomitant disease ${ }^{\star}$ & 7 & 7 & & & \\
\hline Adults, previously healthy & 23 & 16 & - & 7 & - \\
\hline Adults, immunocompromised $\dagger$ & 38 & $32 \S$ & - & 6 & - \\
\hline Adults with joint disorders: & 63 & 8 & 15 & 13 & 27 \\
\hline Osteoarthritis & 28 & 5 & 8 & 4 & 11 \\
\hline Rheumatoid arthritis & 13 & 2 & 5 & 1 & 5 \\
\hline Ankylosing spondylitis & 1 & & & & 1 \\
\hline Psoriatic arthritis & 1 & & & & 1 \\
\hline Juvenile chronic arthritis & 1 & & & & 1 \\
\hline History of joint trauma & 18 & 1 & 2 & 7 & 8 \\
\hline History of tuberculous coxitis & 1 & & & 1 & \\
\hline \multicolumn{6}{|l|}{ Adults, with joint disorders and } \\
\hline immunocompromised $\ddagger$ & 26 & 9 & 10 & 1 & 6 \\
\hline Osteoarthritis & 4 & 2 & & & 2 \\
\hline Rheumatoid arthritis & 19 & 6 & 10 & & 3 \\
\hline History of joint trauma & 3 & 1 & & 1 & 1 \\
\hline \multicolumn{6}{|c|}{$\begin{array}{l}\text { * Sickle cell trait in two cases; bronchial asthma with eczema, Duchenne's muscular dystrophy, history of cardiosurgery, impaired } \\
\text { killing capacity of neutrophils and impaired chemotaxis of neutrophils, each in one case. } \\
\text { † Intravenous drug abuse in } 14 \text { (six HIV infected), diabetes mellitus in } 11 \text {, renal insufficiency in three (two requiring regular } \\
\text { dialysis), hematological malignancy in three, AIDS in two and chronic osteomyelitis in two cases. In one cases each: polymyalgia } \\
\text { rheumatica treated with prednisone, chronic obstructive lung disease intermittently treated with prednisone, leprosy and alcohol } \\
\text { abuse. } \\
\text { † Diabetes mellitus in six, breast cancer in four, renal insufficiency in one, and immunosuppressive medication (prednisone, } \\
\text { methotrexate or azathioprine) in } 18 \text { cases. } \\
\text { Two patients, both intravenous drug misusers, had each two episodes of bacterial arthritis. }\end{array}$} \\
\hline
\end{tabular}

in the other later investigations demonstrated impaired bacterial killing capacity of the granulocytes. Among adults the polyarticular cases were proportionately distributed between those with underlying joint disorders and those without. Five of 16 adults with more than one infected joint had rheumatoid arthritis, in connection with which three were taking prednisone.

\section{SOURCES OF INFECTION}

Table 3 gives the sources of infection according to patient category. In 126 cases $(67 \%)$ the infection was haematogenous, in 62 cases it was direct. In children the sources of haematogenous infection were known in 16 $(44 \%)$. Those that could be determined included infections of the airways in 12 cases and infected skin lesions in four. Among adults it was possible to determine the sources of infection in 60 cases $(67 \%)$. Thirty eight of these were infected skin lesions, 10 of the feet.

Invasive medical interventions distant from the affected joints led to bacterial arthritis of a prosthetic joint in one patient: after cystoscopy without antibiotic prophylaxis infection developed around a total hip prosthesis. Bac- terial arthritis of a native joint caused by an invasive procedure at a distant site occurred in six cases. Bacterial arthritis after an urological intervention developed in a second case: an osteoarthritic knee became infected after the placement of a catheter and lavage of the bladder while taking antibiotics for urinary tract infection. In each case the same bacteria were found in the urine and in the pus from the infected joint. In five cases bacterial arthritis was secondary to an intervention involving the skin. Three of these involved opening and draining of abscesses: one at the injection site in a user of illicit drugs, a second patient needing long term haemodialysis had a panaritium, and a third patient with chronic nontuberculous osteomyelitis elsewhere in the skeleton developed an abscess in the groin. One patient developed a septic shoulder joint after infection at the insertion site of an intravenous infusion needle at the dorsum of the contralateral hand. In another patient the insertion of a right sided subclavian catheter for the administration of cytostatic drugs led to an episode of bacterial arthritis in one ankle and in the right acromioclavicular joint.

Table 2 Infected joints related to route of infection and underlying condition

\begin{tabular}{|c|c|c|c|c|c|c|c|c|c|}
\hline & \multirow[b]{2}{*}{ Total (\%) } & \multicolumn{4}{|c|}{ Haematogenous infection } & \multicolumn{4}{|c|}{ Direct infection } \\
\hline & & All & Children & $\begin{array}{l}\text { Adults without } \\
\text { joint disorder }\end{array}$ & $\begin{array}{l}\text { Adults with joint } \\
\text { disorder }\end{array}$ & All & Children & $\begin{array}{l}\text { Adults without } \\
\text { joint disorder }\end{array}$ & $\begin{array}{l}\text { Adults with } \\
\text { joint disorder }\end{array}$ \\
\hline Sternoclavicular & $4(2)$ & 4 & & 3 & 1 & & & & \\
\hline Shoulder & $9(5)$ & 5 & & 4 & 1 & 4 & & & \\
\hline Elbow & $17(9)$ & 13 & 3 & 3 & $7(1)$ & 4 & & & $4(4)$ \\
\hline Wrist & $13(7)$ & 13 & 2 & 5 & $6(1)$ & & & & \\
\hline Hand joints & $7(4)$ & & & & & 7 & 1 & 6 & \\
\hline Sacroiliac & $2(1)$ & 2 & 1 & 1 & & & & & \\
\hline Hip & $39(21)$ & 24 & 13 & 3 & $8(8)$ & 15 & & 1 & $14(13)$ \\
\hline Knee & $91(48)$ & 68 & 11 & 32 & $25(14)$ & 23 & 1 & 3 & $19(12)$ \\
\hline Ankle & $23(12)$ & 16 & 8 & 6 & 2 & 7 & & 2 & $5(4)$ \\
\hline Foot joints & $9(5)$ & 6 & & 1 & $5(1)$ & 3 & & 2 & \\
\hline All joints & 214 & 151 & 38 & 58 & $55(25)$ & 63 & 2 & 14 & $47(33)$ \\
\hline
\end{tabular}

* Numbers in parentheses refer to cases with infections around prosthetic or osteosynthetic material. 


\begin{tabular}{|c|c|c|c|c|c|c|c|c|c|}
\hline & \multirow[b]{2}{*}{ Total } & \multicolumn{3}{|l|}{ Children } & \multicolumn{5}{|l|}{ Adults } \\
\hline & & $\begin{array}{l}\text { All } \\
\text { children }\end{array}$ & $\begin{array}{l}\text { Previously } \\
\text { healthy }\end{array}$ & $\begin{array}{l}\text { Concomitant } \\
\text { disease }\end{array}$ & $\begin{array}{l}\text { All } \\
\text { adults }\end{array}$ & $\begin{array}{l}\text { Previously } \\
\text { healthy }\end{array}$ & Immunocompromised & $\begin{array}{l}\text { foint } \\
\text { disordert }\end{array}$ & $\begin{array}{l}\text { Foint disorder and } \\
\text { immunocompromised } \dagger\end{array}$ \\
\hline Haematogenous & 126 & 36 & 29 & 7 & 90 & 16 & 32 & $23(15)$ & $19(10)$ \\
\hline Skin & 42 & 4 & 4 & & 38 & 5 & 15 & $10(7)$ & $8(3)$ \\
\hline Upper airways & 4 & 12 & 10 & 2 & 2 & 1 & & & \\
\hline Lower airways & 16 & & & & 6 & 2 & 4 & $1(1)$ & \\
\hline Urinary tract & 7 & & & & 7 & & 1 & 1 & $5(3)$ \\
\hline \multicolumn{10}{|c|}{$\begin{array}{l}\text { Non-sterile intervention distant from } \\
\text { infected joint: }\end{array}$} \\
\hline Skin & 5 & & & & 5 & & 5 & & \\
\hline Urological & 2 & & & & 2 & & & $2(1)$ & \\
\hline Unknown & 50 & 20 & 15 & 5 & 30 & 8 & 7 & $9(6)$ & $6(4)$ \\
\hline Direct & 62 & 2 & 2 & & 60 & 7 & 6 & $40(27)$ & $7(6)$ \\
\hline Joint surgery^ & 40 & & & & 40 & & & $33(25)$ & $7(6)$ \\
\hline Intra-articular injection & 3 & & & & 3 & & & $3(1)$ & \\
\hline Trauma & 13 & 2 & 2 & & 11 & 7 & 1 & $3(1)$ & \\
\hline Infection of overlying skin & 4 & & & & 4 & & 4 & & \\
\hline Chronic osteomyelitis & 2 & & & & 2 & & 1 & 1 & \\
\hline
\end{tabular}

ऋ Included are two therapeutic and one diagnostic arthroscopy.

$\dagger$ Numbers in parentheses refer to cases with infections around prosthetic or osteosynthetic material.

Infections subsequent to direct interventions in joints occurred in 43 patients $(23 \%$ of all patients): after joint surgery in 40, intra-articular injection with corticosteroids in two, and multiple periarticular injections with an anaesthetic in one case. Surgery consisted of placement of a prosthesis in 20 patients, of implantation of osteosynthesis material in 11 , and of joint surgery not involving foreign material in nine patients-included among these were three arthroscopies of the knee, two therapeutic and one diagnostic.

Bacterial arthritis caused by trauma to the joint occurred in 13 patients, among them two children. Both children and seven adults were previously healthy. Eight of 13 patients in this category had bacterial arthritis of a finger or toe joint.

In four patients invasion of the joint by pathogens occurred by contiguity from infectious skin lesions of the overlying skin. In two other patients the source of infection was juxta-articular chronic osteomyelitis, one of them tuberculous.

BACTERIA

Twenty four species of bacteria were identified in cultures of material from infected joints (table 4). Irrespective of clinical category Staphylococcus aureus was the most common, being found in $44 \%$ of all positive cultures. In $72 \%$ of these the strain was penicillin resistant. Streptococci and Gram negative bacilli were the second and third most common categories of bacteria, in 21 and $17 \%$ respectively. Neisseria gonorrhoea was not found.

The most frequently cultured bacteria in children were $S$ aureus and $H$ influenzae. $S$ aureus was cultured exclusively in children younger than 6 months or older than 5 years. $H$ influenzae was found in seven patients, six of them aged between 6 months and 2 years. In all five patients in whom typing of $H$ influenzae was performed, the serotype was $b$. In 12 children no microorganisms were identified.

In adults cultured bacteria in native joints versus joints containing foreign material differed in that Staphylococcus epidermidis, group B streptococcus, group D streptococcus, and Gram negative bacilli were seen more often in the latter.

\section{Discussion}

The overall incidence of bacterial arthritis reported here is somewhat higher than was found in earlier studies. ${ }^{67}$ The difference might be because of the small incidence of underreporting in our study and the increased frequency of surgical joint procedures over the past decade. The cooperation of clinicians and microbiologists from all general hospitals and bacteriological laboratories and, afterwards, from the diagnosis registries in the health district, minimised the chance of underreporting cases. Any underestimation is probably because of unreported occurrences of bacterial arthritis in cases of terminal sepsis and the departure of cases in which patients received early treatment. The region in which the survey took place consisted of two thirds of the habitants of the city of Amsterdam; we have no clues that the observed incidence rate is influenced by the relative often use of drugs or by a higher frequency of AIDS.

Bacterial arthritis occurs most frequently among children and the elderly. In very young children the epiphysis and metaphysis are joined by vascular anastomoses, which may provide additional paths for the dissemination of infection. ${ }^{124}$ Among the elderly in addition to age itself the occurrence of bacterial arthritis is probably related to concomitant joint and immunocompromising disorders. ${ }^{25-27}$ In our survey, $88 \%$ of the patients aged 70 years or older, but only $56 \%$ of the remaining adults, had an underlying joint disease, diabetes mellitus, a malignancy, or was taking immunosuppressive medication.

The clinical profiles of patients with bacterial arthritis are continually changing. ${ }^{5628}$ In our series $56 \%$ of the patients with infections around a prosthesis were aged 70 years or older, forming a group that does not occur in earlier surveys. The percentages of patients using immunosuppressive medication or infected with HIV were also higher than those found in previous studies. ${ }^{26-1129-36}$ To a certain extent these changes may reflect the 
Table 4 Cultured microorganisms in relation to underlying condition

\begin{tabular}{|c|c|c|c|c|c|c|c|c|c|}
\hline \multirow[b]{2}{*}{ Microorganism } & \multirow[b]{2}{*}{ Total ${ }^{\star}$} & \multicolumn{3}{|l|}{ Children } & \multicolumn{5}{|l|}{ Adults } \\
\hline & & All & $\begin{array}{l}\text { Previously } \\
\text { healthy }\end{array}$ & $\begin{array}{l}\text { Concomitant } \\
\text { disease }\end{array}$ & All & $\begin{array}{l}\text { Previously } \\
\text { healthy }\end{array}$ & Immunocompromised & $\begin{array}{l}\text { Foint } \\
\text { disorder }\end{array}$ & $\begin{array}{l}\text { foint disorder and } \\
\text { immunocompromised }\end{array}$ \\
\hline Staphylococcus & $97(48)$ & $9(24)$ & 6 & 3 & $88(53)$ & $9(39)$ & $28(64)$ & $38(52)$ & $13(50)$ \\
\hline$S$ aureus & 23 & 2 & 2 & & 21 & 4 & 9 & 5 & 3 \\
\hline$S$ aureus, penicillin resistant & 60 & 7 & 4 & 3 & 53 & 5 & 18 & 24 & 6 \\
\hline Sepidemidis & 11 & & & & 11 & & 1 & 6 & 4 \\
\hline Species & 3 & & & & 3 & & & 3 & \\
\hline Streptococcus & $37(18)$ & $8(21)$ & 6 & 2 & $9(17)$ & $7(30)$ & $5(11)$ & $15(21)$ & $2(8)$ \\
\hline Group A & 10 & 4 & 4 & & 6 & 3 & 2 & 1 & \\
\hline Group B & 7 & & & & 7 & & 3 & 4 & \\
\hline Group D & 2 & & & & 2 & & & 2 & \\
\hline Group G & 7 & & & & 7 & 1 & & 5 & 1 \\
\hline$S$ pneumoniae & 7 & 4 & 2 & 2 & 3 & 1 & & 1 & 1 \\
\hline$S$ mitis & 1 & & & & 1 & & & 1 & \\
\hline Species & 3 & & & & 3 & 2 & & 1 & \\
\hline Gram negative bacilli & $30(15)$ & $8(21)$ & 7 & 1 & $22(13)$ & $1(4)$ & $5(11)$ & $10(14)$ & $6(23)$ \\
\hline Escherichia coli & 9 & & & & 9 & & & 4 & 5 \\
\hline Proteus mirabilis & 2 & & & & 2 & & & 1 & 1 \\
\hline Klebsiella species & 1 & 1 & 1 & & & & & & \\
\hline Enterobacter cloacae & 2 & & & & 2 & & 1 & 1 & \\
\hline Citrobacter freundii & 1 & & & & 1 & & 1 & & \\
\hline Pseudomonas aeruginosa & 5 & & & & 5 & & 1 & 4 & \\
\hline Haemophilus influenzae & 8 & 7 & 6 & 1 & 1 & & 1 & & \\
\hline Haemophilus parainfluenzae & 1 & & & & 1 & & 1 & & \\
\hline Pasteurella multocida & 1 & & & & 1 & 1 & & & \\
\hline Other bacteria & $16(8)$ & $1(3)$ & 1 & & $15(9)$ & $3(13)$ & $5(11)$ & $6(8)$ & $1(4)$ \\
\hline Bacteroides species & 3 & & & & 3 & & 1 & 2 & \\
\hline Peptostreptococcus prevotii & 1 & & & & 1 & & 1 & & \\
\hline Corynebacterium species & 1 & & & & 1 & & 1 & & \\
\hline Neisseria meningitidis & 2 & 1 & 1 & & 1 & 1 & & & \\
\hline Propionibacterium acnes & 3 & & & & 3 & & & 2 & 1 \\
\hline Borrelia burgdorferi & 1 & & & & 1 & 1 & & & \\
\hline Mycobacterium tuberculosis & 5 & & & & 5 & 1 & 2 & 2 & \\
\hline Unknown & $24(12)$ & $12(32)$ & 1 & 1 & $12(7)$ & $3(13)$ & $1(2)$ & $4(5)$ & $4(15)$ \\
\hline
\end{tabular}

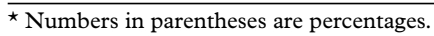

method by which we collected our data. The data in most of the series described in published reports came from the orthopaedic or rheumatological departments of single hospitals rather than from whole districts. ${ }^{26-1129-36}$

A fifth of all patients were aged 15 years or younger; $H$ influenzae was cultured comparatively often in this group. It can be expected that $H$ influenzae type $b$ as a causative organism will decrease in the coming years because of the introduction of an additional national programme of vaccination in children born after 31 December 1992.

Rheumatoid arthritis patients treated with immunosuppressive drugs constituted the majority of the clinical category of 25 adults with an underlying joint disease as well as an immunocompromising condition. Patients with rheumatoid arthritis frequently develop infections at the site of skin defects particularly on the feet. ${ }^{36}$ The integrity of the skin is threatened by deformations, nodules, and atrophy resulting from medication. ${ }^{37}$ In $14(64 \%)$ of the 22 rheumatoid arthritis patients with haematogenous bacterial arthritis infected skin lesions were the sources of infection. These were on the feet in eight patients.

There were only seven cases of bacterial arthritis secondary to medical interventions other than in the joints. A call for reporting similar cases advertised in a national medical journal and in the newsletters of the orthopaedic and rheumatological societies brought just one more to light: an infection with Proteus mirabilis around a hip prosthesis secondary to a dilatation of the urethra without antibiotic prophylaxis. Recently revised national guidelines for patients with hip prostheses call for prevention and early treatment of infections elsewhere in the body and for the prophylactic use of amoxicillin-clavulanate in all patients with prosthetic joints submitted to invasive interventions with risk of bacteraemia. ${ }^{13}$ These guidelines are analogous with those in endocarditis prophylaxis. Experience in the latter however, ${ }^{38} 39$ and the use of antibiotic prophylaxis as reported by patients with joint diseases ${ }^{19}$ show low compliance.

The absence of gonococcal arthritis in our study is remarkable. Despite the additional cooperation of dermatovenereologists in venereal disease outpatient clinics and the occurrence of patients with bacterial arthritis in a subpopulation where gonorrhoea is more frequently seen (six of the 14 users of intravenous drugs were prostitutes), we found no case of gonococcal arthritis. There has been a steep decrease of annual new cases of gonorrhoea, ${ }^{40}$ probably related to safe sex promotional campaigns against AIDS. Another possible reason is that the survey lasted for too short a period to detect a rare disease; before and after the duration of the study a few patients with gonococcal arthritis were seen.

In theory, the potentially preventable cases of bacterial arthritis are those in which there is an impaired immune system at the local or the systemic level and (the threat of) bacteraemia. Immunocompromised patients without joint disorders form a heterogeneous group, not amenable to prophylactic measures directed at preventing bacterial arthritis other than general principles of good clinical care including rapid treatment of infections and alertness in case of bacteraemia. As strict adherence to antiseptic procedures during 
invasive interventions of joints is common practice, not much additional benefit is to be expected in this category. More, however little it may be, is to be expected from the prevention of haematogenous bacterial arthritis among patients with underlying joint diseases. In this study that category was represented by 42 patients, 25 of whom had infections around joint prostheses or osteosynthetic material. Provided the potential source of the infection would have been detected in time, prophylaxis according to the regimen recommended by current consensus would have prevented haematogenous bacterial arthritis in those 25 patients $(17 \%$ of all adult patients). In 10 $(40 \%)$ of these patients however, the source of infection could not be determined. Most potentially preventable cases are patients with infections around joint prostheses and a known haematogenous source; they form 8\% (15 of 188 ) of all cases with joint infection. Whether these cases can really be prevented and how much effort has to be done to get there, remains to be seen.

The authors wish to thank the patients, clinicians, microbiologists, and medical registrars who cooperated in the survey. This study was supported by the Dutch Prevention Fund grant 28-1879.

1 Klein RS. Joint infection, with consideration of underlying diseases and sources of bacteremia in hematogenous infection. Clin Geriatr Med 1988;4:375-94.

2 Gardner GC, Weisman MH. Pyarthrosis in patients with rheumatoid arthritis: a report of 13 cases and a review of rheumatoid arthritis: a report of 13 cases and a review of
the literature from the past 40 years. Am J Med the literature from

3 Goldenberg DL. Infectious arthritis complicating rheumatoid arthritis and other chronic rheumatic disorders. Arthritis Rheum 1989:32:496-502.

4 Kaandorp CJE, Krijnen P, Bernelot Moens HJ, Habbema JDF, Schaardenburg D van. The outcome of bacterial arthritis, a prospective community-based study. Arthritis Rheum 1997;40:884-92.

5 Mikhail IS, Alarcon GS. Nongonococcal bacterial arthritis. Rheum Dis Clin N Am 1993;19: 311-31.

6 Cooper C, Cawley MID. Bacterial arthritis in an English health district: a 10 year review. Ann Rheum Dis 1986;45:458-63.

7 Lidgren L. Orthopaedic infections in patients with rheumatoid arthritis. Scand J Rheumatol 1973;2:92-6.

8 Gristina AG, Rovere GD, Shoji H. Spontaneous septic arthritis complicating rheumatoid arthritis. J Bone Joint Surg 1974;56:1180-4

9 Mitchell WS, Brooks PM, Stevenson RD, Buchanan WW. Septic arthritis in patients with rheumatoid disease: a still
underdiagnosed complication. J Rheumatol 1976;3:12433.

10 Bengtson S, Knutson K. The infected knee arthroplasty. Acta Orthop Scand 1991;62: 301-11

11 Poss R, Thornhill TS, Ewald FC, Thomas WH, Batte NJ, Sledge CB. Factors influencing the incidence and outcome of infection following total joint arthroplasty. Clin Orthop 1984;182:117-26.

12 Blackburn WD, Alarcon GS. Prosthetic joints: a role for prophylaxis. A review. Arthritis Rheum 1991;34:110-7.

13 Revised Consensus Total Hip Prosthesis. In: Everdingen JJE van, ed. Consensus in de geneeskunde. Utrecht: Bunge, 1994 B3/1-24.

14 Brause BD. Infections associated with prosthetic joints. Clin Rheum Dis 1986;12: 523-36.
15 Lattimer GL, Keblish PA, Dickson TB, Vernick CG, Finnegan WJ. Hematogenous infection in total joint replacement. Recommendations
ics. JAMA 1979;242:2213-4.

16 Eskenazi D, Rathbun W. Is systemic antimicrobial prophylaxis justified in dental patients with prosthetic joints? Oral Medicine 1988;66:430-1.

17 Simmons NA, Ball AP, Cawson RA, Eykyn SJ, Hughes SPF, McGowan DA, et al. Case against antibiotic prophylaxis for dental treatment of patients with joint prostheses. Lancet 1992;339:301.

18 Thyne GM, Ferguson JW. Antibiotic prophylaxis during dental treatment in patients with prosthetic joints. J Bone Joint Surg 1991;73:191-4.

19 Kaandorp CJE, Schaardenburg D van, Krijnen P, Habbema JDF, Laar MAFJ van de. Risk factors for septic arthritis in patients with joint diseases. A prospective study. Arthritis patients with joint diseases.
Rheum 1995;38:1819-25.

20 Amsterdam in numbers 1992. Amsterdam: Stadsdrukkerij Amsterdam, 1992.

21 Newman JH. Review of septic arthritis throughout the antibiotic era. Ann Rheum Dis 1976;35:198-205.

22 Schmalzried TP, Amstutz HC, Au MK, Dorey FJ. Etiology of deep sepsis in total hip arthroplasty. Clin Orthop 1992; 280:200-7.

23 Gray RG, Tenenbaum J, Gottlieb NL. Local corticosteroid injection treatment in rheumatic disorders. Semin Arthritis Rheum 1981;10:231-54.

24 Nade S. Acute septic arthritis in infancy and childhood. J Bone Joint Surg 1983;56: 234-41.

25 Cooper C, Cawley MID. Bacterial arthritis in the elderly. Gerontology 1986;32:222-7.

26 Lagaay AM, Asperen van IA, Hijmans W. The prevalence of morbidity in the oldest old, aged 85 and over: a population based survey in Leiden, The Netherlands. Arch Gerontol Geriatr 1992;15:115-31.

27 Wade AW, Green-Johnson J, Szewczuk MR. Functional changes in systemic and mucosal lymphocyte repertoires with age: an update review. Aging Immunol Infect Dis 1988;1:65-97.

28 Ang-Fonte GZ, Rozboril MB, Thompson GR. Changes in nongonococcal septic arthritis: drug abuse and methicillinresistant Staphylococcal aureus. Arthritis Rheum 1985; 28:210-3

29 Peters RHJ, Rasker JJ, Jacobs JWG, Prevo RL, Karthaus RP. Bacterial arthritis in a district hospital. Clin Rheumatol 1992;11:351-5.

30 Meijers KAE, Dijkmans BAC, Hermans J, Broek PJ van den, Cats A. Non-gonococcal infectious arthritis: a retrospective study. J Infect 1987;14:13-20.

31 Soria LM, Sole JMN, Sacanell AR, Garcia JV, Escofet DR. Infectious arthritis in patients with rheumatoid arthritis. Ann Rheum Dis 1992;51:402-3.

32 Ostensonn A, Geborek P. Septic arthritis as a non-surgical complication in rheumatoid arthritis: relation to disease severity and therapy. Br J Rheumatol 1991;30:35-8.

33 Rosenthal J, Bole GG, Robinson WD. Acute nongonococcal infectious arthritis. Evaluation of risk factors, therapy and infectious arthritis. Evaluation of risk factors,

34 Manshady RH, Thompson GR, Weiss JJ. Septic arthritis in a general hospital 1966-1977. J Rheumatol 1980;7:52330.

35 Maderazo EG, Judson S, Pasternak H. Late infections of total joint prostheses. A review and recommendations for prevention. Clin Orthop 1988;229:131-42.

36 Morris IM, Eade AWT. Pyogenic arthritis and rheumatoid disease: the importance of the infected foot. Rheum Rehab 1978;77:222-6.

37 Thurtle OA, Cawley MID. The frequency of leg ulceration in rheumatoid arthritis: a survey. J Rheumatol 1983; 10:507-9.

38 Meer JTM van der, Thompson J, Michel M, Valkenburg HA. Epidemiology of bacterial endocarditis in the Netherlands: II. Antecedent procedures and use of prophylaxis. Arch Intern Med 1992;152:1869-73

39 Meer JTM van der, Wijk W van, Thompson J, Valkenburg HA, Michel MF. Awareness of need and actual use of prophylaxis: lack of patient compliance in the prevention of bacterial endocarditis. J Antimicrob Chemother 1992; 29:187-94.

40 Annual report of sexually transmitted diseases. Amsterdam: Gemeentelijke Geneeskundige en Gezondheidsdienst, 1992. 